\title{
MANFAAT RENCANA MUTU DALAM PENGENDALIAN PROSES PERANCANGAN ARSITEKTUR MELALUI PENERAPAN SISTEM MANAJEMEN MUTU ISO 9001
}

\author{
Budi Heriyanto $^{1 *}$, I Gede Oka S. Pribadi ${ }^{2}$ \\ 'Mahasiswa Program Studi Magister Arsitektur, Universitas Trisakti, *sadana_m15@yahoo.com \\ ${ }^{2}$ Dosen Program Studi Magister Arsitektur, Universitas Trisakti
}

\begin{abstract}
ABSTRAK
Dalam bidang jasa perencanaan arsitektur, rencana mutu merupakan bentuk komitmen antara penyedia jasa terhadap pengguna jasa, dan menunjukkan langkah yang akan diambil dalam memenuhi harapan pengguna jasa terkait dokumen perancangan yang akan dihasilkan. Rencana mutu disusun berdasarkan pemahaman yang mendalam terhadap jenis dan sifat kegiatan dan diuraikan dalam langkah strategis untuk mencapai kinerja yang optimal, sesuai persyaratan dari pengguna jasa. Disusun menjadi sebuah dokumen informatif, dengan mempertimbangkan interaksi yang terjadi antara pelaku dan kegiatannya dalam mencapai sasaran mutu yang ditetapkan melalui metode, prosedur maupun rujukan yang diperlukan. Rencana mutu akan bermanfaat apabila dilaksanakan sebagai pedoman pengendalian secara konsisten,dan apabila terjadi hal-hal diluar rencana maka harus segera disesuaikan. Dengan demikian rencana mutu merupakan dokumen yang terpelihara. Walaupun setiap kegiatan dalam proses perancangan arsitektur mempunyai fenomena yang berbeda, tetapi tahap pekerjaannya dapat diurutkan, sehingga rencana mutu dapat digunakan untuk memantau berjalannya proses perancangan sesuai tahap yang dilaksanakan.
\end{abstract}

Kata kunci-dokumen, komitmen, terpelihara.

\begin{abstract}
In the architectural planning organization, a quality plan is a form of commitment between service providers and users. It shows the direction of meeting user expectation regarding the design documents that will be produced. The quality plan is arranged based on an indepth understanding of the type and trait of activities and also described in strategic action to achieve an optimal performance, according to the user requirements. It is compiled into an informative document by considering the interactions that occur between the subject and its activities determined through the methods, the procedures, and the references needed. The quality plan will be useful if carried out as a control guide consistently and if things happen outside the plan then it must be adjusted immediately. Thus, the quality plan becomes a maintained document. Although every activity in the architectural design process has a different phenomenon, the work stages still can be sorted. So that the quality plan can be used to monitor the design process according to the stage implemented.
\end{abstract}

Keywords - commitment, document, maintained.

\section{PENDAHULUAN}

Proses perancangan arsitektur adalah kegiatan menyiapkan dokumen perancangan berupa gambar, rencana kerja dan syarat-syarat termasuk perhitungan anggaran dan volume pekerjaan yang dilakukan oleh penyedia jasa perencanaan baik secara perorangan maupun organisasi. Konsultan Perencana merupakan salah satu bentuk organisasi penyedia jasa konstruksi 
pada bidang perencanaan, salah satu layanan usahanya adalah perancangan arsitektur. Kualaifikasi dan klasifikasinya diatur dalam undang-undang termasuk pemenuhan syarat jika pekerjaannya beresiko besar, berteknologi tinggi dan/atau berbiaya besar.

Pada Proyek pemerintah dengan tingkat kompleksitas tinggi dipersyaratkan mempunyai sistem manajemen mutu yang dapat menjamin tercapainya kualitas sesuai yang diharapkan. Sistem Manajemen Mutu (ISO) 9001 merupakan pedoman yang dianjurkan oleh pemerintah untuk diterapkan pada bidang jasa konstruksi termasuk jasa perencanaan konstruksi. Dalam penerapan sistem tersebut dikembangkan persyaratan untuk menyusun rencana mutu. Dengan memandang bahwa kegiatan akan berjalan dengan baik dan mencapai sasaran yang tepat, memerlukan perencanaan yang sesuai, maka rencana mutu kegiatan proses perancangan arsitektur perlu disusun dengan memperhatikan persyaratan dari pengguna jasa, maupun cara mencapai pemenuhannya. Rencana mutu semestinya menjamin kualitas hasil proses perancangan arsitektur, namun demikian masih terjadi permasalahan pada saat pelaksanaan konstruksi, maupun sesudah obyek perancangan tersebut digunakan akibat kurang optimal dokumen perancangannya. Dengan demikian perlu dipahami kriteria yang diperlukan dalam menyusun rencana mutu, dan bagaimana penerapannya sehingga dapat memberikan arah mengenai kegiatan yang akan dilaksanakan sesuai pengendalian yang diterapkan.

Sementara itu rencana mutu pada organisasi perencana kurang mendapat perhatian dibandingkan pada pelaksana konstruksi, terbukti pada penelitian terhadap 10 dokumen pengadaan perencana hanya pengguna jasa dari kementerian PUPR yang mensyaratkan penyusunan rencana mutu.

\section{Tinjauan Teori}

Dalam penelitian ini lebih banyak mengacu pada kegiatan pelaksanaan konstruksi oleh pemerintah, dimana kegiatannya diatur dalam persyaratan peraturan dan undang-undang. Penyedia jasa perencanaan konstruksi adalah perusahaan yang memenuhi persyaratan untuk melaksanakan tugas konsultansi dalam bidang jasa perencanaan teknis bangunan beserta kelengkapannya (Peraturan Menteri Pekerjaan Umum nomor 45/PRT/M/2007, tentang Pedoman Teknis Pembangunan Bangunan Gedung Negara). Dalam peraturan tersebut diatur tentang tahap pekerjaan yang harus dilalui dan pihak-pihak yang terlibat dalam pelaksanaan konstruksi. Konsultan perencana adalah orang/badan yang melaksanakan pekerjaan perencanaan. Pemilik proyek atau pemberi tugas atau pengguna jasa adalah orang/badan yang memiliki proyek dan memberikan pekerjaan kepada pihak penyedia jasa melalui kontrak pekerjaan. Tata cara pengadaan jasa konstruksi diatur dalam Peraturan Menteri Pekerjaan Umum Nomor 07/PRT/M/2011 Tentang Standar dan Pedoman Pengadaan Pekerjaan Konstruksi dan Jasa Konsultansi .

Dalam menjamin kualitas pekerjaan, penyedia jasa menyusun perencanaan mutu terhadap tahapan proses kegiatan dan hasil kegiatan sebagaimana yang dipersyaratkan dalam pekerjaan yang disebut sebagai 
Rencana Mutu Kontrak (RMK) dan diatur dalam Peraturan Menteri Pekerjaan Umum Nomor: 04/PRT/M/2009, Tentang Sistem Manajemen Mutu (SMM) Departemen Pekerjaan Umum.

RMK merupakan bentuk dari perencanaan kegiatan yang diformulasikan dalam sebuah dokumen. Perencanaan diperlukan untuk mencapai sebuah tujuan, termasuk kegiatan proses perancangan arsitektur. Kegiatan tersebut membutuhkan suatu perencanaan yang benar-benar matang dengan meletakkan dasar dari tujuan dan sasaran proyek sekaligus menyiapkan semua program teknis dan administrasi agar dapat diimplementasikan. Tujuannya yaitu supaya memenuhi persyaratan spesifikasi yang ditentukan dalam batasan waktu, mutu, biaya maupun keselamatan kerja (Program Studi Teknik Lingkungan Fakultas Teknik Universitas Diponegoro, 2016).

RMK sekurang-kurangnya harus memuat informasi proyek, metode kerja proyek, jadwal pelaksanaan proyek, jadwal kegiatan verifikasi, jadwal penyediaan sumber daya keuangan dan sebagainya, Mulyo et.al (2005:58), Panduan Penerapan Manajemen Mutu ISO 9001: 2000. Lebih jauh dijelaskan RMK harus didukung oleh dokumen sistem manajemen mutu yang cukup dan harus disimpan serta mudah diperoleh. Dengan demikian RMK merupakan media komunikasi dan kordinasi pada anggota tim yang terlibat dalam kegiatan. Apabila terjadi ketidaksesuaian proses yang ditetapkan RMK, maka harus dilakukan perbaikan. Persyaratan RMK dalam Sistem Manajemen ISO 9001 masuk dalam klausul perencanaan realisasi produk.
Sistem Manajemen Mutu ISO 9001 merupakan sistem yang dianjurkan untuk diterapkan pada jasa konstruksi melalui surat edaran Menteri Pekerjaan Umum 03/SE/M/2005 dan 08/SE/M/2006, sampai saat ini masih diterapkan pada bidang Jasa Konstruksi kelas besar dengan jenis pekerjaan kompleksitas tinggi. Dari teori-teori tersebut dapat disusun Kerangka teori yang terkait antara persyaratan dari pengguna jasa dan pemenuhan persyaratan oleh penyedia jasa, melalui penyusunan dokumen rencana mutu (RMK) berdasarkan penerapan Sistem Manajemen Mutu ISO 9001 dan peraturan-peraturan terhadap penyedia jasa konstruksi oleh pemerintah.

\section{METODE PENELITIAN}

Metode yang digunakan adalah metode deskriptif untuk menggambarkan fenomena-fenomena yang ada dalam menyusun rencana mutu pengendalian pelaksanaan proyek perencanaan arsitektur. Penelitian dilakukan terhadap organisasi perencana yang menerapkan SMM ISO 9001 maupun dokumen rencana mutu kontrak sebagai unit amatan dengan mengacu pada peraturan yang berlaku pada saat dokumen disusun.

Penelitian sebatas pada rencana mutu yang disusun organisasi dalam pengendalian proses perancangan arsitektur. Masukan-masukan berkaitan dengan penyusunan RMK melalui penerapan SMM ISO 9001 merupakan data yang terpisah pisah tetapi mempunyai keterkaitan, secara induktif disatukan dan dianalisa untuk mendapatkan kesimpulan berkaitan dengan 
kriteria yang diperlukan dalam melakukan penilaian terhadap manfaat penyusunan rencana mutu.

\section{PEMBAHASAN}

Dalam sistem pengadaan jasa perencanaan oleh pemerintah, penyedia jasa perencanaan ditunjuk setelah melalui proses penawaran dengan mengajukan proposal biaya,administrasi dan teknis berdasarkan kerangka acuan kerja (KAK) yang disusun oleh pengguna jasa. Proposal teknis antara lain memuat pemahaman terhadap kegiatan akan dilaksanakan, program kerja, jadwal pelaksanaan, komposisi tim dan tenaga ahli yang diusulkan dan jadwal penugasannya. Ketika kemudian organisasi perencana ditunjuk sebagai pelaksana kegiatan, maka apa yang diajukan pada saat penawaran akan diverifikasi termasuk proposal teknisnya. Hasil verifikasi proposal teknis antara pengguna jasa dan penyedia jasa menjadi dasar penyusunan rencana mutu kontrak. Sebagai penyedia jasa, organisasi perencana melengkapi rencana mutu kontrak dengan aspek yang diperlukan antara lain informasi tambahan dari pengguna jasa, prosedur dan metode kerja yang diterapkan untuk mencapai mutu meliputi pengendalian SDM, waktu dan produksi dokumen. dengan demikian dapat dipahami bahwa dasar penyusunan RMK adalah Masukan untuk penyusunan RMK berdasarkan Kerangka Acuan Kerja, Proposal pada tahap marketing, Dokumen prosedur kerja, Peraturan-peraturan terkait, Rujukan yang relevan.

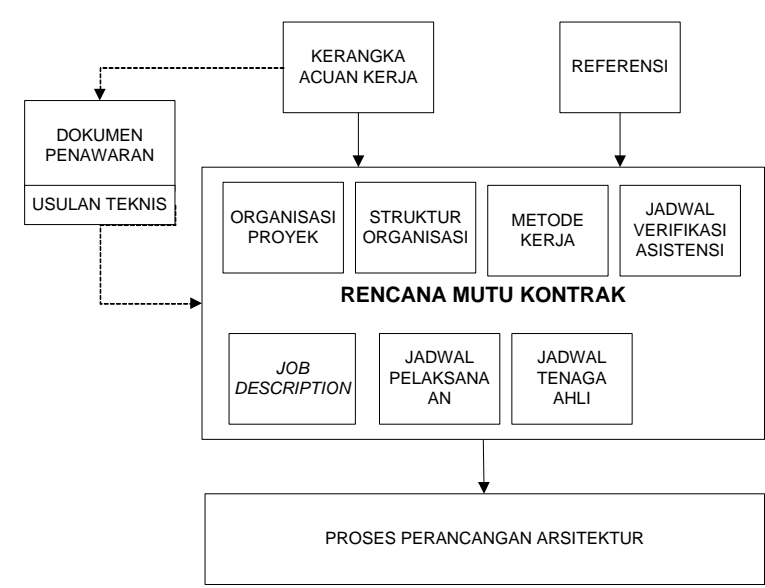

Gambar 1. Dasar Penyusunan Rencana Mutu (Sumber : hasil analisis, 2018)

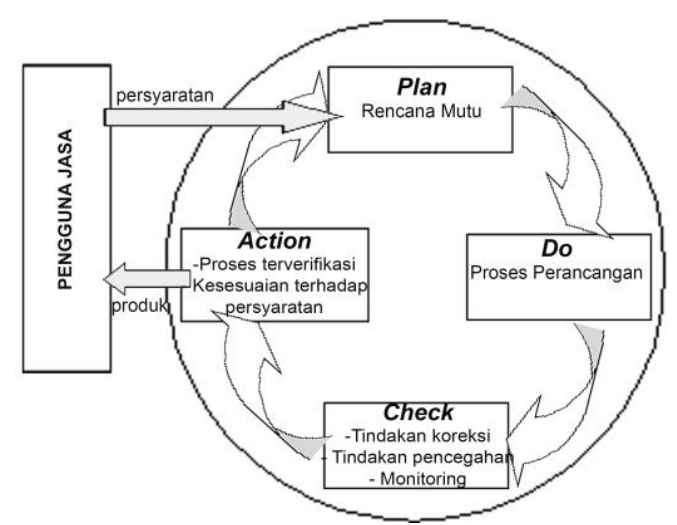

Gambar 2. Rencana Mutu pada Konsep PDCA (Sumber : hasil analisis, 2018)

Dalam standar SMM ISO yang menekankan bahwa setiap kegiatan dilaksanakan melalui proses Plan, Do, Check, Action (PDCA), maka Rencana Mutu Kontrak 
merupakan aspek perencanaan yang digunakan sebagai panduan untuk melaksanakan sebuah proses kegiatan, dan akan dimonitor dan diverifikasi secara terus menerus (Gambar 2.).

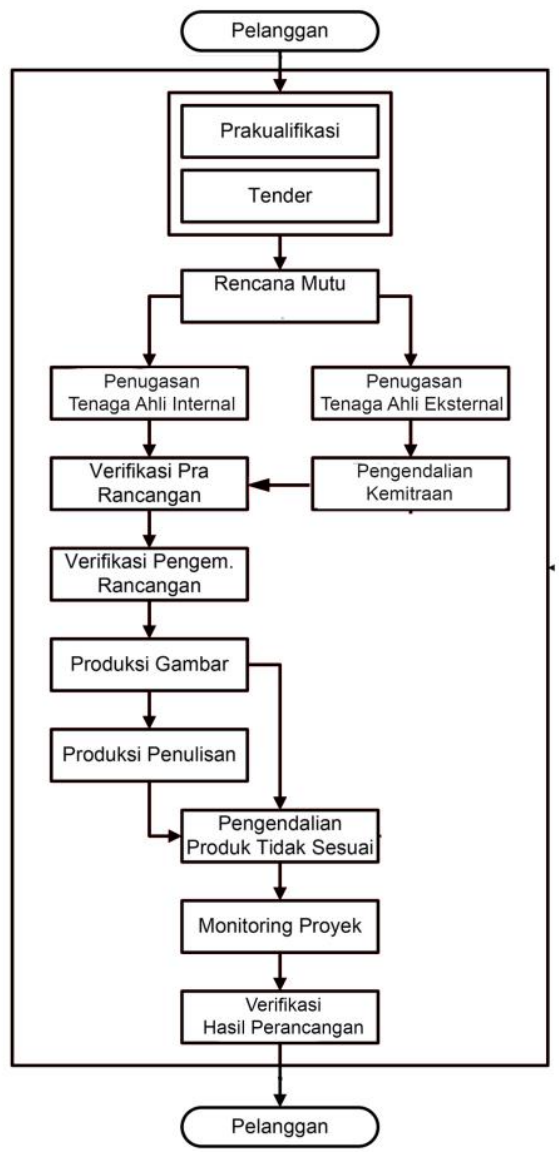

Gambar 3. Kedudukan Rencana Mutu pada Proses Perancangan Arsitektur (Sumber: PT.Cakra Manggilingan Jaya, 2018)

\section{Penyusunan dan Penerapan Rencana Mutu pada Konsultan Perencana Arsitektur}

Rencana mutu dalam istilah pengadaan proyek pemerintah disebut sebagai Rencana Mutu Kontrak dikembangkan berdasarkan Kerangka Acuan Kerja dari pengguna jasa dan proposal teknis dari penyedia jasa yang diterapkan pada awal kegiatan sebagai bentuk komitmen dan panduan pelaksanaan kegiatan. Bisnis utama organisasi perencana arsitektur adalah menyediakan jasa perencanaan dan perancangan.

\section{Isi Rencana Mutu}

Dalam penelitian ini didapat masukan berupa contoh susunan rencana mutu yang disiapkan organisasi perencana arsitektur PT. Cakra Manggilingan Jaya.

- Kebijakan mutu dan sasaran mutu proyek. Mengingat organisasi tersebut menerapkan SMM ISO 9001 maka kebijakan maupun sasaran mutu mengacu pada sistem tersebut.

- Informasi tentang proyek. Menginformasikan nama, lokasi, nilai proyek, nomor kontrak, cara pembayaran, masa pelaksanaan.

- Lingkup proyek. Menguraikan lingkup pekerjaan perancangan, batasan perancangan.

- Lokasi Proyek. Menggambarkan secara jelas lokasi proyek, hubungannya dengan wilayah kota dan jaringan jalan dalam sebuah peta.

- Metode Kerja. Dalam penyusunan RMK dapat digambarkan melalui skema atau bagan alir yang menunjukkan proses masing-masing kegiatan yang berlangsung, interaksi antara pelaku kegiatan dan aktivitasnya, maupun sasaran yang dicapai. 


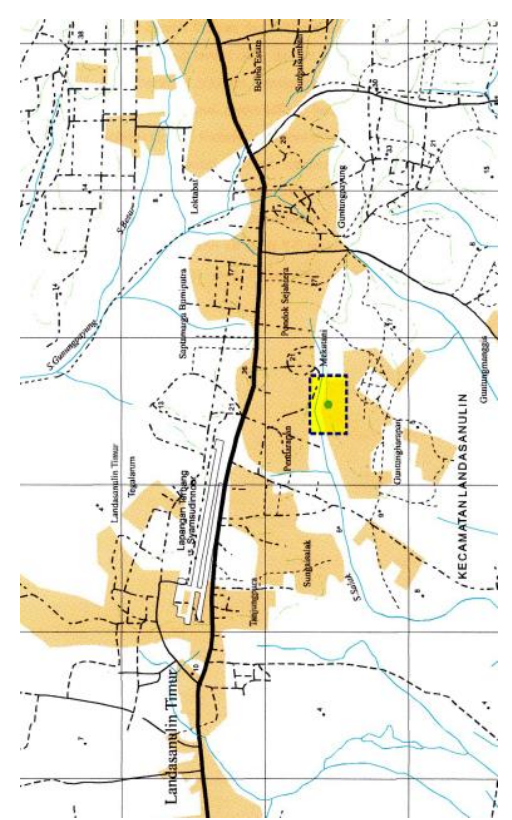

Gambar 4. Peta Lokasi (Sumber: PT.Cakra Manggilingan Jaya, 2008)

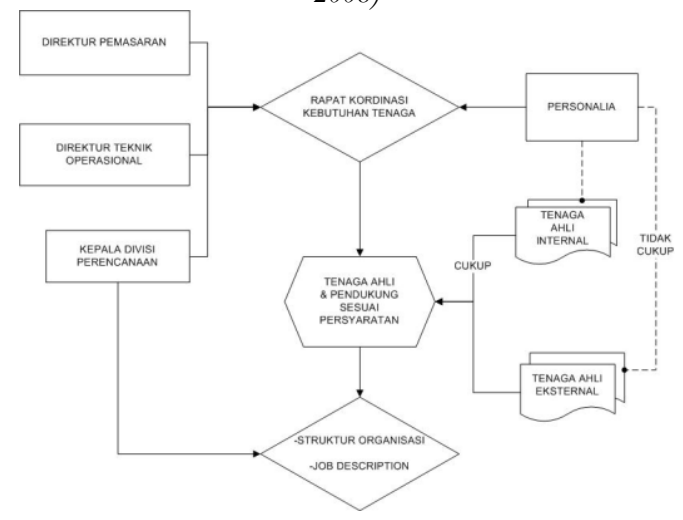

Gambar 5. Metode Pengendalian Tenaga Ahli (Sumber: PT.Cakra Manggilingan Jaya, 2018)

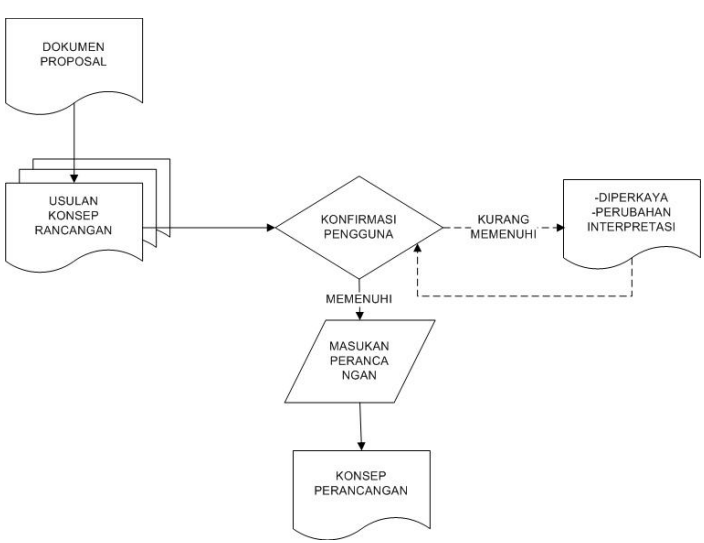

Gambar 6. Metode Interpretasi Kerangka Acuan Kerja (Sumber: PT.Cakra Manggilingan Jaya, 2018)

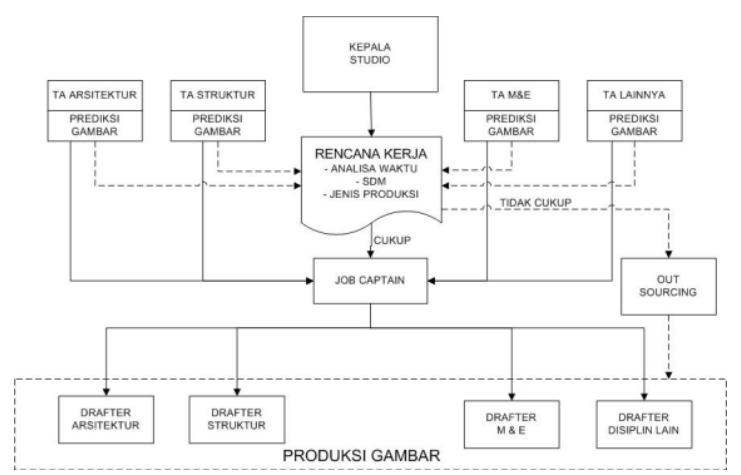

Gambar 7. Metode Produksi Gambar (Sumber : PT.Cakra Manggilingan Jaya, 2018)

- Pihak-pihak yang terlibat dalam proyek. Menjelaskan siapa saja yang terkait dalam pelaksanaan proyek perancangan digambarkan dalam diagram interaksi. 
SKEMA ORGANISASI PROYEK

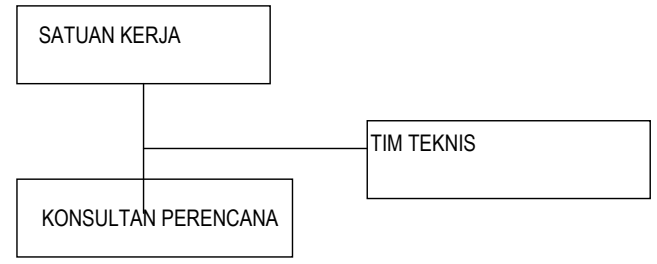

Gambar 8. Skema Organisasi Proyek (Sumber: PT.Cakra Manggilingan Jaya, 2008)

- Struktur Organisasi Pelaksana Proyek. Menggambarkan secara diagramatis struktur organisasi penanganan pelaksanaan proyek perancangan arsitektur.

- Hubungan antar lembaga, intansi yang terkait dalam proses perencanaan diketahui bersama, dan memudahkan untuk proses diskusi, konsultasi, verifikasi.

- Struktur Organisasi Kerja yang jelas akan memudahkan kordinasi secara internal, maupun eksternal.

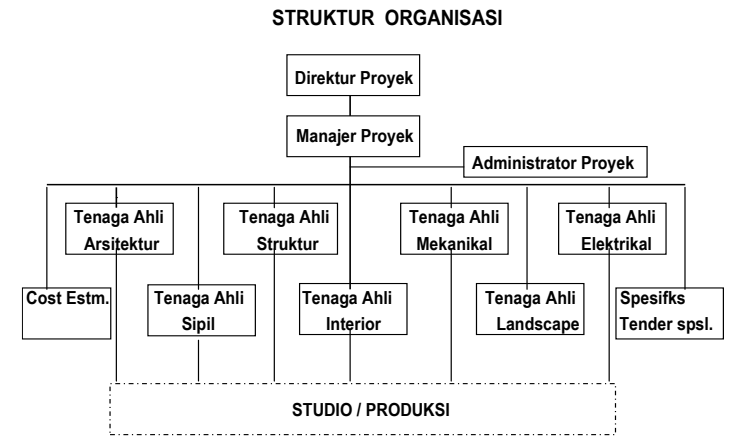

Gambar 9. Skema Organisasi Proyek (Sumber: PT. Cakra Manggilingan Jaya, 2008)
- Tugas dan Tanggung Jawab. menguraikan hak dan kewajiban masing-masing yang terlibat dalam pelaksanaan pekerjaan sesuai Struktur organisasi proyek.

- Jadwal Pelaksanaan. Jadwal pelaksanaan kegiatan disusun dalam Barchart, merupakan media komunikasi dalam pengendalian waktu bagi masingmasing yang terlibat dalam proses perancangan arsitektur.

- Jadwal Keterlibatan Tenaga Ahli. Memperlihatkan keterlibatan Tenaga Ahli dan berfungsi dalam pengendalian waktu dan kordinasi lintas disiplin.

- Jadwal verifikasi, Asistensi dan Persetujuan. Merupakan media komunikasi bagi semua pihak yang terlibat dalam proses perancangan arsitektur mengenai target waktu yang direncanakan untuk mendapatkan persetujuan melalui proses verifikasi dan asistensi kepada pemberi tugas. Jadwal yang tersusun dalam RMK ini dapat dikembangkan sebagai monitoring proyek yang di update secara berkala baik berupa barchart atau curva S.

- Daftar Referensi. Memperlihatkan referensi yang digunakan sebagai rujukan dalam proses kegiatan, antara lain peraturan-peraturan, standar ukuran ruang, harga satuan bangunan, dokumentasi proyek yang relevan.

Dalam proses perancangan arsitektur terdapat dua jenis kegiatan utama, pertama adalah kegiatan proses kreatif dan pemikiran yaitu, pada tahap konsep perancangan hingga pengembangan rancangan. Yang kedua adalah proses produksi yaitu pada tahap Detail Engineering Design (DED), terdiri dari produksi 
dokumen gambar, dokumen penulisan perhitungan dan laporan. Walaupun masing-masing kegiatan juga saling berinteraksi tetapi secara proporsional terdapat perbedaan. Dalam Rencana mutu dua jenis kegiatan tersebut sudah diperhitungkan resiko yang mungkin terjadi. Misalnya pada tahap proses kreatif, persetujuan design mengalami keterlambatan yang signifikan dan berakibat pada proses produksi dengan tidak tercapainya waktu yang ditetapkan, hal tersebut sudah diantisipasi melalui tindakan pencegahan atau penanganan produk tidak sesuai.. Rencana mutu kemudian perlu dikomunikasikan dan dikordinasikan pada masing-masing yang terlibat, termasuk kepada pengguna jasa.

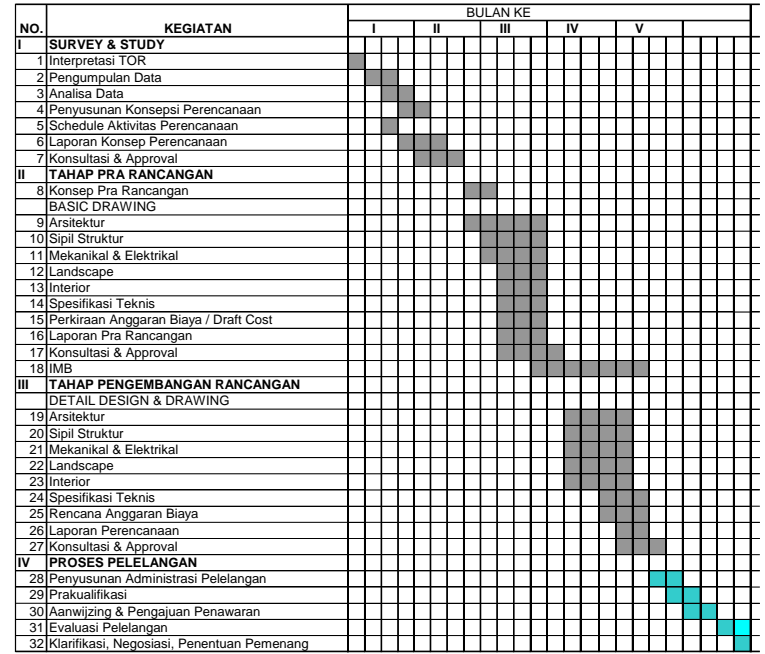

Gambar 10. Jadwal Kegiatan Perancangan Arsitektur (Sumber: PT. Cakera Manggilingan Jaya, 2010)

\section{Manfaat Penyusunan Rencana Mutu}

Sejak penyusunannya yang melibatkan diskusi tenaga ahli lintas disiplin dalam memahami kerangka acuan kerja, RMK sudah mempunyai manfaat sebagai media komunikasi dan kordinasi dalam memahami permasalahan penugasan, sehingga setiap anggota tim mempunyai pemahaman yang sama terkait sasaran yang akan dicapai.

Metode kerja yang disusun dalam dokumen rencana mutu merupakan panduan yang memudahkan anggota tim menjalankan kegiatan sekaligus memonitor progress pekerjaan. Dalam RMK yang mengacu pada SMM ISO 9001, dengan penekanan konsep Plan-Do-Check-Action, maka RMK merupakan dokumen yang terpelihara dan memberikan pedoman mengenai tindakan pencegahan,maupun tindakan koreksi, yang diperlukan agar rencana mutu tercapai.

Rencana mutu selain bertujuan pada kepuasan pelanggan juga dapat memberi gambaran berapa nilai profit atau keuntungan yang akan didapat melalui penyusunan anggaran proyek. Hal tersebut menjadi perangsang anggota tim dalam melaksanakan sesuai tugas dan mencapai kulitas yang baik.

\section{Permasalahan pada Pelaksanaan Rencana Mutu}

Organisasi perencana dapat mengembangkan pengendalian proses perancangan arsitektur melalui penyusunan rencana mutu yang matang tetapi dalam penerapannya dapat terjadi hal-hal diluar yang rencana yang tidak dapat dihindari akibat faktor eksternal antara lain: perubahan lingkup tugas, perubahan waktu, 
perubahan fungsi bangunan, berlarutnya approval. Dari sisi internal ketidak sesuaian terhadap rencana mutu dapat disebabkan kendala kemampuan personil, dukungan alat kerja. Jika tidak dilakukan penyesuaian maka tim kerja akan kehilangan arah dan dokumen rencana mutu tidak berguna. Dalam sistem pengendalian proses perancangan arsitektur, Rencana Mutu hanya merupakan salah satu bagian tetapi mempunyai peranan penting dalam memberikan arah tercapainyai hasil perancangan yang baik.

\section{KESIMPULAN}

Walaupun pekerjaan perancangan arsitektur berkaitan dengan proses kreatif, tetapi dalam proyek pemerintah dibatasi dengan peraturan-peraturan yang berlaku dan dibatasi dengan waktu maupun biaya yang sudah ditetapkan. Oleh sebab itu perlu diatur penyusunan rencana mutu yang merupakan bentuk komitmen tercapainya kualitas yang diinginkan termasuk kesesuaian terhadap waktu dan hasil pekerjaan sesuai anggaran yang terdia. Tidak optimalnya tahap proses kreatif terhadap rencana mutu, akan berakibat pada pekerjaan engineering dan produksi selanjutnya.

Bagi organisasi perencana sebaiknya menyusun Rencana Mutu terlepas dipersyaratkan atau tidak mengingat selain menjadi media komunikasi antar penyedia jasa dan pengguna jasa, juga menjadi media informasi, komunikasi dan kordinasi antar anggota tim pelaksana dalam mencapai sasaran mutu.
Adanya dokumen rencana mutu (RMK) akan memperlihatkan kemampuan dan kesungguhan organisasi perencana sebagai organisasi yang dapat dipercaya dan kualitas kinerjanya terjamin, hal ini akan meningkatkan nilai jualnya. Apabila terjadi ketidaksesuaian antara rencana mutu yang telah ditetapkan terhadap realita, maka RMK harus segera disesuaikan, kemudian dikomunikasikan dan dikordinasikan kembali sehingga berfungsi sebagai bagian dari pengendali proses kegiatan.

\section{REFERENSI}

Badan Pembinaan Konstruksi Kementerian PU. (2014). Peraturan Pemerintah Nomor 4 Tahun 2010.

Cognoscenti. (2015). Standard Internasional ISO 9001 : 2015.

http://www.hukumonline.com/pusatdata/detail/2470 1/node/329/surat-edaran-menteri-pekerjaanumum.(2018)

http://www.hukumonline.com/pusatdata/detail/2090 1/node/lt51d0f0c73a191/se-menteri-pekerjaanumum, (2018)

Mulyo,Sutedjo,Ariyanti,Kartasasmita,Djatnika,Rahenya ntono,Gondowardoyo,Heriyanto,Hadi,(2005)Pa nduan Penerapan Manajemen Mutu ISO 9001 :2000, LPJK, PT Elex Media Komputindo.

Peraturan Menteri Pekerjaan Umum Nomor 45/PRT/M/2007, Pedoman Teknis Pembangunan Bangunan Gedung Negara. 
Program Studi Teknik Lingkungan Fakultas Teknik Universitas Diponegoro (2016), Manajemen Proyek Pembangunan SPAM. 